This item was submitted to Loughborough's Research Repository by the author.

Items in Figshare are protected by copyright, with all rights reserved, unless otherwise indicated.

\title{
Politically connected boards and top executive pay in Chinese listed firms
}

PLEASE CITE THE PUBLISHED VERSION

http://dx.doi.org/10.1002/smj.2253

PUBLISHER

(c) John Wiley \& Sons, Ltd

VERSION

AM (Accepted Manuscript)

\section{PUBLISHER STATEMENT}

This work is made available according to the conditions of the Creative Commons Attribution-NonCommercialNoDerivatives 4.0 International (CC BY-NC-ND 4.0) licence. Full details of this licence are available at: https://creativecommons.org/licenses/by-nc-nd/4.0/

\section{LICENCE}

CC BY-NC-ND 4.0

\section{REPOSITORY RECORD}

Chizema, Amon, Xiaohui Liu, Jiangyong Lu, and Lan Gao. 2014. "Politically Connected Boards and Top Executive Pay in Chinese Listed Firms". Loughborough University. https://hdl.handle.net/2134/16712. 
POLITICALLY CONNECTED BOARDS AND TOP EXECUTIVE

PAY IN CHINESE LISTED FIRMS

\author{
Amon Chizema \\ Loughborough University \\ School of Business and Economics \\ LE11 3TU \\ Leicestershire \\ UK \\ E-mail: A.Chizema@lboro.ac.uk \\ Tel: 01509228807 \\ Xiaohui Liu \\ Loughborough University \\ School of Business and Economics \\ LE11 3TU \\ Leicestershire \\ UK \\ E-mail: $\underline{\text { X.Liu2@lboro.ac.uk }}$ \\ Tel: 01509223349 \\ Jiangyong Lu \\ Guanghua School of Management \\ Peking University \\ Beijing, China, 100871 \\ Email: lujiangyong@gsm.pku.edu.cn \\ Tel: +86(0)10 62757913

\section{Lan Gao} \\ Loughborough University \\ School of Business and Economics \\ LE11 3TU \\ Leicestershire \\ UK \\ E-mail:1.gao@lboro.ac.uk
}




\begin{abstract}
Drawing on social comparison theory this study examines the relationship between politically connected boards and top executive pay. Moreover, given the socialist orientation of China, tests are also carried out to establish the relationship between politically connected directors and pay dispersion across the firm. We find a negative association between politically connected boards and top executive pay. We also find that politically connected boards are negatively associated with pay dispersion, i.e. the higher the number of political directors on the board the smaller the gap between top executive pay and average employee pay. Finally, our study shows that politically connected directors weaken the pay-performance link. These findings have important theoretical, policy and managerial implications.
\end{abstract}

Key words: top executive pay; politically connected directors; China; social comparison theory; corporate governance 


\section{POLITICALLY CONNECTED BOARDS AND TOP EXECUTIVE PAY IN CHINESE LISTED FIRMS}

\section{INTRODUCTION}

The question of whether the composition of the board of directors has much impact on organizational outcomes is centrally important to a wide array of research agendas in strategic management, including studies on executive compensation (Carpenter and Sanders, 2002; Conyon, Peck and Sadler, 2001). Accordingly, a body of research has been devoted to the question of whether and under what circumstances board structure, its composition and other governance factors matter in affecting executive compensation (e.g., Dalton, Daily, Ellstrand and Johnson, 1998). However, the relation between top executive compensation and board composition has been examined in many prior empirical papers with mixed findings (Gomez-Mejia, 1994). For example, Lambert, Larcker and Weigelt (1993) document a positive relation between CEO compensation and the percentage of the board composed of outside directors, whereas Finkelstein and Hambrick (1989) find that compensation is unrelated to the percentage of outside directors on the board.

Drawing on agency theory (Fama and Jensen, 1983), some of these studies have explored the relationship between executive compensation and the monitoring role of outside directors (Daily, Dalton and Cannella, 2003; Kumar and Sivaramakrishnan, 2008). In this respect, Boyd (1994) finds that CEO salaries were greater in firms with lower levels of control. Wright, Knoll and Elenkov (2002) find that post-acquisition firm size drives CEO compensation in firms with lax monitoring but post-acquisition performance drives CEO compensation in vigilantly monitored firms. 
While these prior studies point to the role of outside directors (in general) in executive pay determination, little is known about the impact of politically connected outside directors on executive compensation despite being more sophisticated and successful in gaining board seats (Stern and Westphal, 2010), holding values and beliefs consistent with their political ideology ${ }^{1}$ (Chin, Hambrick and Trevino, 2013) and being present in many countries (Agrawal and Koeber, 2001; Faccio, 2006). To remedy this omission, we draw on social comparison theory to examine the impact of politically connected boards on executive pay in Chinese listed firms. Specifically, we investigate whether politically connected boards are associated with lower or higher levels of top executive compensation.

We also test for the effects of political connections on pay dispersion, contributing to the literature on pay dispersion that has generally tended to focus on the consequences rather than antecedents of pay disparity (e.g., Carpenter and Sanders, 2002; Graffin, Wade, Porac and McNamee, 2008). Finally, we take a step further and investigate the moderating role of politically connected boards on the performance-pay relationship.

A politically connected board has at least one director who was a former politician, including a member of parliament, a minister or any other top appointed government bureaucrat or officer in a state-owned enterprise (Faccio, 2006). As such politically connected directors may help reduce uncertainty for the firm by connecting the firm to the government and influential politicians, bringing information, skills, and legitimacy to the firm (Hillman, 2005).

In this study the institutional context is set in China, in relation to the politically connected board's strategic and governance attitude towards executive pay.

\footnotetext{
${ }^{1}$ Political ideology is normally defined as an interrelated set of attitudes, behaviours and values about the goals of society and how they should be achieved. It helps to explain why people do what they do through their values and beliefs (Jost, 2006).
} 
Chinese boards are characterized by the presence of politically connected directors (Buck, Liu and Skovoroda, 2008; Firth, Fung and Rui, 2006). In fact, until recently all executive appointments within Chinese firms were made by the state and executive pay was calculated according to seniority and civil service formulae that implied equality or near-equality between workers and managers (Firth et al., 2006). However, following changes to Company Law in 1994, boards of listed firms are arguably free to appoint executives and set their own executive pay that, in many firms, is limited to basic salary and bonuses (Buck et al., 2008).

While recent studies have investigated executive pay in China (e.g., Buck et al., 2008; Firth, Fung and Rui, 2007; Kato and Long, 2006), none of them have explicitly examined the effect of politically connected directors on top executive remuneration. Yet, in the case of China, where the economy has achieved spectacular growth despite minimum political reform, a deeper understanding of the role played by political connections in business is necessary.

Differing from previous studies, we develop our arguments drawing on social comparison theory and the political ideology of outside directors, underscoring the salience of the institutional environment in executive pay determination. Here, we heed to the call by scholars (e.g., Filatotchev and Allcock, 2010) who have suggested that executive pay should be understood within the context of both the organization and its surrounding environment.

Extending prior research on executive pay, our study makes several contributions. First, a focus on China is theoretically and empirically important, because it allows us to investigate the determinants of executive pay in an underexplored context. Given the fact that much of the research in executive remuneration is western-based, our study helps extend existing research to a rich and complex 
context beyond that of developed economies, contributing to the literature on executive remuneration in general and to pay studies in emerging markets in particular. Specifically, findings from this study will provide new insights into how special features of the institutional environment, such as political connections, affect executive pay, an aspect that has largely been overlooked in the governance literature.

Second, our study provides an understanding of the effects of directors' ideological background on firm decision making, in general, and on executive compensation in particular. While several studies in corporate governance have explored specific characteristics of directors and their strategic choices (Carpenter, Geletkanycz and Sanders, 2004; Guner, Malmendier and Tate, 2008; Fich and Shivdasani, 2006; Hillman, Cannella and Harris, 2002), little is known about corporate decision making as a function of directors' political orientation and socialization. Thus, our paper responds to the recent call by Chin et al., (2013) who suggest that executives' political ideologies might be manifested in an array of organizational attributes and decisions beyond CSR practices (the subject of their focus).

This represents an important direction, given that political connections are rooted in the institutional context of China and have profound implications for firm strategies and performance. Examining the relationship between politically connected boards and executive pay helps advance our understanding of the governance and monitoring role of outside directors in executive pay. Moreover, this study provides further evidence to the growing literature on the implications of political connections in the business world, in particular on the impact of political connections on top executive pay. 
Third, our study adds to the sparse literature on the determinants of pay dispersion within firms. Most prior theorizing and research on executive compensation has emphasized the effects of pay differences across firms (e.g., Milkovich, Gerhart and Hannon, 1991), thus neglecting the antecedents of pay dispersion between top executives and the general employees. Thus, our study provides new insights into the antecedents of pay dispersion in the context of China, a country with deep-seated socialist traditions, where notions of pay equality or near equality have traditionally been emphasized (Firth et al., 2006).

The remainder of this paper is organized as follows. The next section presents theory and hypotheses. This is followed by the methodology section after which we present our results. The penultimate section is on discussion, and we conclude in the last one.

\section{THEORY AND HYPOTHESES}

\section{Social comparison theory}

A number of studies examining the determination of top executive compensation have used a variety of theoretical lenses. Most of this research has been predicated on economic theories, including neoclassical notions of marginal product (e.g., Baker, Jensen and Murphy, 1988), human capital theory (Hogan and McPheters, 1980), transaction cost economics (Ofek and Yermack, 2000), agency theory (Gibbons and Murphy, 1992; Tosi, Katz and Gomez-Mejia, 1997), tournament theory (Conyon et al., 2001; Main, O’Reilly and Wade, 1993) and managerial power theory (Bebchuk and Fried, 2004; Bebchuk, Fried and Walker, 2002).

Studies based on economic theory are typical attempts to show that CEO compensation conforms to some theoretical perspectives, such as agency or tournament theory. On the other hand, socio-psychological approaches begin with the 
premise that the compensation-setting process relies on the deliberations of a small group of people who may be affected by a number of psychological and political processes that shape individual and group decisions everywhere (Ezzamel and Watson, 1998). A study by O’Reilly, Main and Crystal (1988) found that the pay of members of the compensation committee, mostly outside directors, was a better predictor of top executive pay than were economic factors such as firm performance and human capital measures. Thus, the conclusion from this study was that top executive pay could be explained in terms of a social comparison process.

The theory of social comparisons, proposed by Festinger (1954), underlies much of the research in equity and organizational justice (Walster, Berscheid and Walster, 1973). Research has shown that social comparisons in organizations may lead to feelings of inequity (Kulik and Ambrose, 1992; Wade, O’Reilly and Pollock, 2006), which have in turn been linked to lower productivity at both the organizational and individual levels, loss of group cohesion, theft, lower quality and increased turnover (Bloom, 1999; Pfeffer and Langton, 1993; Zenger, 1992).

According to the theory of social comparison processes, social actors and decision makers of all kinds have to routinely rely upon a whole range of social comparisons to secure equity in the setting up of their expected rewards. Indeed, Festinger (1954) noted that individuals have a need to evaluate their opinions and abilities. Such an evaluation can be made by comparing oneself against others who are perceived to have abilities similar to one's own (Fredrickson, Davies-Blake and Sanders, 2010). In line with Festinger's formulation of social comparison theory, O’Reilly and colleagues indicated that "when making comparisons, individuals are likely to select as comparisons others who are seen as slightly better or more expert” (1988: 262). 
Interpreting these arguments, Ezzamel and Watson (1998) suggest that nonexecutive directors are chosen because of their similarity to those who are involved in the selection process. They further propose that in setting executive cash compensation, members of a compensation committee gather information from their own experiences, either as serving executives or as non-executive directors of other firms, and the analyses provided by external pay consultants concerning similar executives in the most successful comparator firms or in those that provide betterthan-average pay. This has particular implications for both the level of top executive remuneration and pay dispersion across the firm.

\section{Politically connected directors and top executive compensation}

Previous studies have shown the relationship between various forms of outside directors and executive compensation. For example, Hallock (1997) shows that CEO compensation is higher at firms with interlocked outside directors. Lambert et al. (1993) find that CEOs receive higher pay when they have appointed a greater proportion of the board. Dalton et al (1998) find no support for the proposition that the board compensation committee influences pay levels or the use of performancecontingent pay, while Deutsch (2005) finds, in a meta-analysis, that the proportion of outside directors is generally negatively associated with the use of CEO performance contingent pay. Core, Holthausen and Larcker (1999) show that CEO pay decreased with the percentage of inside directors, but increased with board size, the percentage of outside directors appointed by the CEO, the percentage of gray outside directors ${ }^{2}$, the percentage of outside directors over the age of sixty-nine and the percentage of outside directors who serve on three or more boards.

\footnotetext{
${ }^{2} \mathrm{~A}$ gray director is one that is not employed by the firm, but may have some sort of affiliation, which can cause a conflict of interest. Ex-employees, CEOs of a partnering firm and the CEOs family members are examples of typical gray directors.
} 
These studies are part of the broad literature that examines the agency role of directors, referring to the governance function in which directors serve shareholders by ratifying the decisions of managers and monitoring the implementation of those decisions (Baysinger and Hoskisson, 1990; Daily and Dalton, 1997; Fama and Jensen, 1983). As such the agency role has also been termed the control role of boards (Johnson, Daily, Ellstrand, 1996), with a focus on the important monitoring and governance function (Daily et al., 2003). Of course, another distinct role that directors play is that of providing and securing essential resources for the firm through linkages to the external environment (Hillman, 2005; Hillman and Dalziel, 2003; Pfeffer and Salancik, 1978).

While the monitoring and resource provision functions are more likely to be straightforward in countries where government intervention in business is kept at a minimum (Faccio, 2010), we argue that this may not be the case where the outside director is politically connected and particularly if he/she had a former political appointment, as is commonly the case in China.

We argue further that in China, a country with a socialist tradition, the role played by politically connected directors in corporate decision making is likely to be influenced by their political ideology, reflecting state policies or objectives. Here, the politically connected director may play a useful role to the organization, helping the firm to gain preferential treatment by state-owned enterprises such as banks (Cull and Xu, 2005; Faccio, 2006; Johnson and Mitton, 2003), enabling lighter taxation (De Soto, 1989), preferential treatment in competition for government contracts (Dinç, 2004; Goldman, Rocholl and So, 2008), relaxed regulatory oversight of the company in question (Faccio, 2010) and government aid in times of financial trouble (Faccio, Masulis and McConnell, 2006). On the other hand, the politically connected director 
may ensure that the state's political expectations are met by the firm (Boycko, Shleifer and Vishny, 1996; Cull and Xu, 2005; Du and Girma, 2010).

In the context of executive pay, we argue, therefore, that the presence of politically connected directors in Chinese firms may determine the level of executive pay in a manner that reflects the political priorities and norms of the state (Mengistae and $\mathrm{Xu}, 2004)$. Such norms are rooted in the political ideology that emphasizes equality of income. Thus, paying high executive compensation can be viewed as stretching the boundary and socially unacceptable (Markoczy, Sun, Peng, Shi and Ren, 2013).

First, drawing on social comparison theory, politically connected directors may potentially make comparisons between pay in the civil service with that of the companies they serve as outside directors. This comparison may be shaped by their socialization as well as their experiences as current or former civil servants ${ }^{3}$. This suggests that politically connected directors are likely to recommend pay levels similar to those in the civil service, directly reflecting their current or previous earnings.

Social comparison theory argues that individuals routinely compare themselves with referent others whom they see as being similar on attributes such as demographic characteristics, ability, or position (Festinger, 1954). Indeed, like top executives, politically connected directors are likely to be highly motivated, achievementoriented, power-seeking, and status-driven (Finkelstein and Hambrick, 1996). In short, top executives as well as politically connected directors have succeeded in

\footnotetext{
${ }^{3}$ Civil servants in China include personnel in Party organizations, the People's Congresses, the People's Political Consultative Conferences, the judicial and procuratorial organizations (Chan and Li, 2007). This effectively makes all politically connected directors former or current civil servants.
} 
getting to their respective levels, in part, because they are highly competitive, which makes them particularly prone to make social comparisons of pay (Lazear, 1989).

However, when compared with the private sector, civil service pay in China, despite going through several reforms, is lower (Chan and Ma, 2011) and even lower for directors of state-owned enterprises (SOEs), from where politically connected directors with business expertise are likely to be drawn. This is because before the 1980s, the Chinese SOE was the lowest link in the chain of command of the central planning machinery (Mengistae and $\mathrm{Xu}, 2004$ ). This was a setting that made the enterprise director less of a business executive than a civil servant responsible for the implementation of a set of planned targets routinely passed down by a national or regional planning hierarchy. The director was thus evaluated and compensated accordingly and came under the overseeing authority of the enterprise Communist Party Committee, the secretary of which had a greater voice than the director. By virtue of being former or current civil servants, politically connected directors share this history and socialization, and this experience could potentially influence board decision-making processes. Layman (1997) shows that individuals' values are reflected in their political behaviors and decision making processes. Thus, while executive compensation in China is generally low by international standards (Buck et al., 2008; Conyon and He, 2011; Kato and Long, 2006), by local standards it is likely to be lower in firms with higher proportions of politically connected directors.

Second, high levels of top executive compensation generally are unpopular with the public, even in Western economies (Bebchuk and Fried, 2004), as they attract attention from the media. In the context of our study, the government may consider awarding high levels of compensation to executives as unfair income distribution (Markoczy et al., 2013) and thus a red button that potentially triggers public outrage 
costs (Adithipyangkul, Alon and Zhang, 2011; Firth et al., 2006). Consequently, this potential outcry may trigger the intervention of government officials at national level and politically connected directors at firm level.

Having established the motive by politically connected directors in China to keep executive compensation at low levels, an important issue to address is their capability to influence the pay-setting process. We argue that politically connected directors have the power and legitimacy to influence executive compensation because they are connected to the state that is dominant and still plays a significant part in business (Markoczy et al., 2013). Indeed, the state still controls access to critical resources such as raw materials and capital (Keister, 2004). In deciding the level of executive compensation Chinese firms are, therefore, influenced by the views of the state and those of its ideologically-affiliated actors, such as politically connected directors. Given the motive and capability by politically connected directors to influence decisions in their favor we suggest:

Hypothesis 1: There is a negative association between politically connected boards and top executive compensation.

\section{Political connections and pay dispersion}

An area of academic research closely related to the issue discussed above is that of pay dispersion in firms. Pay dispersion refers to the amount of difference (inequality) in pay created by a firm’s pay structure (Milkovich and Newman, 1999).

Research has yielded mixed results about what amount of pay dispersion is optimal and about its effects in firms. Some researchers draw on tournament theory and argue that pay dispersion has positive effects because it promotes competition, encouraging top talent to rise to the top (Lazear and Rosen, 1981). Others adopt perspectives rooted in social-psychological arguments, such as social comparison 
theory and suggest that pay dispersion is associated with increased executive turnover and decreased firm performance (Bloom and Michel, 2002; Siegel and Hambrick, 2005).

While most of these studies have considered the consequences of pay dispersion, however, not much is known about its antecedents. Like studies on consequences, the limited research on the antecedents of pay dispersion draws on social comparison theory, examining teams such as top executives and comparing the pay of directors on the same board (e.g., Fredrickson, et al., 2010).

This paper deviates from previous studies in that rather than examine pay differentials among top executives, we consider the set of all company employees including top executives as one big team. We consider that beyond the comparison that politically connected directors are likely to make between civil service and private sector pay, the issue of pay differentials within the firm is another area of interest and importance, given the unique institutional context of China.

Indeed, politically, China is a socialist country that arguably places importance on equality (or near equality) of pay between managers and workers (Adithipyangkul et al., 2011), a view echoed culturally by a high level of collectivism (Hofstede, 2003) and reduced managerial discretion (Crossland and Hambrick, 2011). In fact, the 1956 civil service pay reform and several others that followed up until 1986 compressed occupational differentials in pay (Shi and Wu, 1993).

We argue that politically connected directors are more likely to push for lower pay dispersion in firms. However, the amount of pressure for pay compression depends partly on opportunities that politically connected directors have to make social comparisons of pay. For example, Leventhal (1976 found that people in groups that had a high level of interaction preferred equal rewards. Similarly, Pfeffer and 
Langton (1988) reported that in public colleges and universities, where compensation is a matter of public record, pay was more compressed among both faculty and highlevel administrators, than in private institutions, where such pay information is not in the public domain. Politically connected directors in China have both the motive and opportunity to make comparisons of different levels of pay. First, they have knowledge of civil service pay that is highly compressed due to China's political ideology of equality. Such knowledge comes from their previous experience of civil service or their close association with the state. Second, by virtue of having a seat on the board they have knowledge of employees’ and top executives’ pay in the firm and the opportunity to determine the latter. Thus, making direct comparisons with the situation in the civil service, indeed from where they draw their experience, opinions and behavior for comparison purposes (Festinger, 1954), politically connected directors are likely to influence low executive pay such that the gap between top executives’ and company employees’ pay is reduced. We therefore suggest:

Hypothesis 2: Politically connected boards will be associated with low pay dispersion.

\section{The moderating role of political connections between performance and pay}

A positive relationship between firm performance and top executive compensation is consistent with agency theory, the dominant paradigm in this stream of research (Jensen and Murphy, 2010; Rost and Osterloh, 2009). Within this framework, managers are self-serving and compensation serves as a motivator that aligns the interests of managers with those of shareholders (Jensen and Murphy, 2010). In this context, the extent to which shareholders' agency problems are resolved has traditionally been assessed by associating executive pay with the performance of the firm (Fama and Jensen, 1983). 
Among many measures of performance, previous studies have used return on assets (ROA), return on sales (ROS) and total shareholder return, and the responsiveness of pay to performance has been measured by pay-performance sensitivity or elasticity (e.g., Buck et al., 2008; Kato and Long, 2006). Table 1 shows pay-performance sensitivities and elasticities found in previous studies, for USA, UK, Korea and Chinese firms, including the current study. The simple interpretation is that the higher the responsiveness, the lower the level of rent-extraction by the agent, thus the better the link between performance and pay (see a footnote to Table 1 for further explanation).

\section{Insert Table 1 near here}

While some authors have documented a strong and positive link between firm performance and directors’ pay (e.g., Murphy, 1999; Rost and Osterloh, 2009), other studies have not established this relationship (e.g., Bebchuk and Fried, 2004;Tosi, Werner, Katz and Gomez-Mejia, 2000). In the context of China, many studies on top executive pay have shown a positive association between performance and executive compensation (e.g., Buck et al., 2008; Chen, Liu and Li, 2010; Conyon and He, 2011; Firth et al., 2007; Kato and Long, 2006; Mengistae and Xu, 2004).

However, this relationship has not been examined in the presence of political connections. Earlier we argued that politically connected boards, consistent with social comparison theory, are more likely to keep top executive compensation at lower levels, at least in line with civil service remuneration. This suggests that any advice or suggestions given by politically connected directors may be a function of social processes, failing to embrace the economic or agency theoretic assumption that links performance to executive pay. This implies that apart from the direct impact of politically connected directors on top executive pay, their presence may also 
indirectly affect the link between performance and top executive pay. As we discussed above, politically connected directors are more likely to compare top executive pay with that of civil servants based on their own experience and socialization. As discussed earlier too, civil service pay is arguably low and highly compressed, with no regard for different levels of individual performance. By applying the same formula to executive pay, politically connected directors depart from market-based recommendations, potentially obscuring the often assumed positive link between firm performance and top executive pay. Put differently, the involvement of politically connected directors promotes the norms and values of the state for equality of pay, suggesting the possibility of low executive compensation even in the face of improved firm performance. We, therefore, suggest that:

Hypothesis 3: Politically connected boards weaken the link between top executive pay and firm performance.

\section{METHOD}

\section{Data and sample}

To test our hypotheses, we draw our sample from Chinese firms that are listed on the Shanghai and Shenzhen Stock Exchanges. We collected information on top executive pay and characteristics of the board of directors from firms' annual reports for the years 2002 through 2008. We chose 2002 as the starting year for two reasons. First, the Chinese government put great emphasis on corporate governance, following China's access to the World Trade Organization (WTO) at the end of 2001. Second, annual reports for years earlier than 2002 provide less detailed information on the characteristics of the board of directors. We focused on firms whose annual reports can be obtained from Shanghai and Shenzhen Stock Exchanges, the website of the China Security Regulation Committee (CSRC), and the websites of listed firms for 
the six years from 2002 to 2008. Our sample consists of 964 listed firms and the majority of them were in the manufacturing sector. We excluded firms in the financial sector because financial firms have different financial structures, disclosure regimes and ways of measuring their performance. Moreover, the financial sector is heavily regulated by the Chinese government, making it difficult to examine the role of political connections in the context of such a regulated sector.

\section{Dependent variables}

We use two dependent variables: top executive cash pay (TE Cash pay) and pay dispersion. Top executive pay was measured by salaries and bonuses and was calculated as the logarithm of average cash pay for the three highest-paid executives at 2000 prices. To capture the pay dispersion in a firm we followed Bloom (1999) by using the ratio of the average employee's pay to the average of top three executive pay. Thus, a lower ratio indicates greater pay dispersion between workers and top executives.

\section{Independent variables}

\section{Political connections}

In order to evaluate the impact of politically connected boards, we focus on outside directors who have had a political background. We define an outside director with political connections as one who was formerly a government officer or member of the Chinese People's Congress (CPC) or the Chinese People's Political Consultative Conference (CPPCC) at county and above levels. We identify whether an outside director was a government official before joining the listed firm from the "Profile of Directors and Senior Managers” section of the company's annual reports. The political connections were measured as a ratio of outside directors who were formerly government officials to the total number of board directors. 


\section{Firm performance}

Return on sales (ROS) is used to measure firm performance. This variable is included in our estimation equations in order to test the moderating effect of political connections on the relationship between executive pay and firm performance.

\section{Control variables}

Given that state-owned enterprises enjoy preferential status in obtaining loans and other key inputs (Brandt and Li, 2003; Che, 2002), we control for state ownership. State shareholding, is calculated as the percentage of shares owned by the central government, local governments and government related agencies. We follow the methodology by Delios, $\mathrm{Wu}$, and Zhou (2006) to categorize ownership in Chinese listed firms according to the ultimate identity of shareholders. We also include foreign shareholding to control for the influence of foreign investors. We control for the impact of board directors by including board size in our estimations that is measured as the total number of board directors. We also include top executive equity ownership, calculated as the percentage of total equity owned by top executives in a firm. We control for firm size and firm age since larger and older firms may pay more for top executives. Firm size and firm age are measured by the logarithm of firm total assets and the number of years since establishment respectively. We include debtequity ratio to control for slack resources. We also control for cross listing. Based on information on whether firms have listed outside mainland China, from the company's annual reports, we created a dummy variable which takes the value of one if firms have been cross listed in international exchanges, and zero otherwise. We also control for the average age of top executives and CEO change. We used industry dummies to control for industry effects and year dummies to control for time varying effects. 


\section{Method of analysis}

Before testing our hypotheses, we first consider sample selection bias by testing which types of firms are likely to have politically connected directors. In order to test for sample selection bias, we created a dummy variable which takes the value of 1 if a firm has a politically connected outside director and 0 otherwise. We estimated a binary logit model to check what types of firms are likely to have politically connected directors. For the explanatory variables, we included firm size, age, state shareholdings, foreign shareholdings, cross listing, industry dummies and a year dummy, when the government required that one third of board directors should be outside directors.

To test whether politically connected directors directly influence top executive pay (H1) and indirectly affect the link between executive pay and performance (H3), we take account of the possibility of a two-way causality between performance and top executive compensation. On one hand, firm performance may affect the level of executive remuneration, an observation that has been made in the literature (Kato and Long, 2006). On the other hand, executive pay may create motivational incentives which help to enhance firm performance (Buck et al., 2008). If reverse causation exists, the impact of firm performance on executive pay would be overstated when using OLS with the fixed effects model. In such a situation, the generalized method of moments (GMM) should be applied to take the interconnectedness of top executive pay and firm performance into account. GMM is widely used to deal with the endogeneity problem in panel data analysis as this method is sufficiently flexible to control for unobserved heterogeneity and endogeneity. In particular, Blundell and Bond (1998) suggest that GMM estimation is an appropriate approach to short panel data as it allows for a large set of instruments of both lagged levels and first 
differences and, therefore, exploits fully all of the available moment conditions. This yields better predictions for the endogenous explanatory variables in the finite sample. We adopt this approach to test our hypotheses.

To test hypothesis 2 which predicts that pay dispersion will decrease as political connections increase, we follow Papke and Wooldridge (1996) by first performing a logit transformation on pay dispersion in order to map the ratio to the whole scale. This is explained by the equation: $P D=\ln$ (Pay Dispersion/(1-Pay Dispersion), where $P D$ is the ratio variable with a value between 0 and 1 . We thus use the transformed $P D$ variable as the dependent variable in the pay dispersion model.

\section{RESULTS}

Table 2 reports descriptive statistics and the correlation matrix for the study variables. The correlations among independent variables are very low. According to our data, the average board size is 9 . State share holdings account for $32 \%$ of the ownership of the sample firms, whereas $6 \%$ of the sample firms are cross-listed.

\section{Insert Table 2 near here}

The results of sample selection bias test presented in Table 3 show that the variables relating to firm characteristics are insignificant These results show that the variable for political connections is weakly exogenous to firm characteristics. Hence, sample section bias is not a concern in our study.

\section{Insert Table 3 near here}

The endogeneity test reveals two-way causality between executive pay and firm performance (Hausman test $=80.318, \mathrm{p}<0.001$ ), suggesting that executive pay 
and performance mutually affect each other (Buck et al., 2008; Kato and Long, 2006). The significant reverse causation indicates that there is also feedback from pay to performance and should be taken into account in modelling the link between executive pay and performance. Based on the results from causality tests, we estimate the direct and indirect impact of political connections on top executive pay by applying GMM to take two-way causality into account. We used lagged variables as instruments that are commonly used to address the endogeneity problem in GMM estimation (Baum, Schaffer and Stillman, 2003). The consistency of the GMM estimator depends on the validity of the instrumental variables used in the regression. We conducted the Sargan test to verify whether the instrumental variables are uncorrelated to residuals and whether they are acceptable instruments. The insignificant results from the Sargan test in Table 4 indicate that the instrumental variables are appropriate.

The results obtained from GMM estimations are shown in Table 4. In Model 1 the main effects of the independent variables were estimated with top executive pay as the dependent variable and the proportion of political connected directors and firm performance as independent variables in the pay equation. The interaction term between political connections and firm performance was included in Model 2.

\section{Insert Table 4 near here}

Hypothesis 1 posits that there is a negative association between politically connected boards and top executive compensation. Results in Models 1and 2 in Table 4 indicate that the variable of political connections is significant and negatively associated with executive remuneration at $(\beta=-0.361, p<0.01)$ in Model 1 and at $(\beta=-$ 0.257, $p<0.1$ ) in Model 2. Hypothesis 1 is, therefore, supported. 
Hypothesis 2 predicts that politically connected boards will be positively associated with low pay dispersion. The results presented in Table 5 show that the coefficient for political connections is statistically significant and positively associated with a low level of pay dispersion $(\beta=0.528, p<0.05)$, suggesting that politically connected directors favor a smaller pay gap between workers and executives. Thus, we found empirical evidence that supports Hypothesis 2.

\section{Insert Table 5 near here}

From the control variables, state shareholding and CEO change have the similar effect as the political connection variable. Firm performance, foreign shareholding, cross listing, board size, debt-equity ratio, firm age and firm size are negatively associated with the pay dispersion, indicating that these factors contribute to a larger pay gap.

Hypothesis 3 predicts that politically connected boards weaken the impact of firm performance on executive pay. To test this hypothesis, we add interactive variables-political connections and firm performance in Model 2 in Table 4. The individual coefficients of political connections and firm performance now represent conditional rather than additive effects, and hence their respective coefficients diverge from those in previous models (Friedrich, 1982). In Model 2, the inclusion of the interaction term improves the model $R^{2}$ from 0.242 to 0.266 . Model 2 shows support for the conditional impact of firm performance on executive pay. In the absence of political connections (i.e. when political connections equal 0), the effect of performance on executive pay is positive and significant $(\beta=0.453 ; p<0.01)$. However, in the aftermath of introducing politically connected directors the effect of performance on pay is reduced, as shown by a negative and significant coefficient ( $\beta=-2.938 ; p<0.05)$. When the proportion of politically connected directors equal 0.039 
(the average), the conditional impact of firm performance on executive pay is [0.453$2.938 *(0.039)=0.338 ;$ s.e. $=0.115 ; p<0.05]$. This suggests that when the proportion of political connections increases to 0.039 , top executive pay is reduced by 40.2 percent [100(exp(0.338)-1)]. Based on these results, Hypothesis 3 is supported.

For the purpose of determining the range of political connections over which the effect of performance on executive pay is significantly reduced, we follow the guidelines by Brambor, Clark and Golder (2006) and thus plot the marginal effect of performance on executive pay on the condition of political connections (Figure 1). When both upper and lower 95\% confidence interval lines (broken lines) are above or below the zero line, firm performance has a statistically significant effect on executive pay. The lower 95\% confidence interval line crossed the zero line when the rate of politically connected directors equals 0.127 under which the conditional impact of firm performance on executive pay is $[0.453-2.938 *(0.127)=0.080$; s.e. $=0.040$; $p<0.05]$. Therefore, when political connections are between 0 and 0.127 , performance has a statistically significant effect on executive pay. When the proportion of political connected directors is above 0.127, the marginal effect of performance on pay becomes insignificant. The graphical display in Figure 2 shows the main effect of political connections and performance on top executive pay and the interaction term between the two. It clearly shows that political connections weaken the positive link between firm performance and executive pay. Executive pay is reduced when political connections increase, given the same level of firm performance.

\section{Insert Figures 1 and 2 near here}

\section{Robustness tests}

In Hypothesis 2 we proposed that politically connected boards reduce pay dispersion. We found support for this hypothesis. However, when this result is considered 
alongside the finding in Hypothesis 1, that political connections reduce executive pay, it may be possible that pay dispersion decreases primarily because of the lowering of executive pay. It is also possible that reduced pay dispersion could be due to political directors influencing an increase in employees' pay. To be certain about the effect of political connections on pay dispersion, we carried out further tests. We ran regression tests with average pay as a dependent variable. The results in Table 5 show that political connections do not have a significant effect on average employee pay ( $\beta=0.004$, insignificant). This suggests that the reduction in the pay gap is mainly due to the negative association between political connections and executive pay.

For all the hypotheses, we reran our regression tests using an alternative measure of performance-return on assets (ROA). Overall, the results are substantively similar to our primary results, pointing to their robustness ${ }^{4}$.

\section{DISCUSSION}

At a broader level, this study relates to two main strands of the literature: the first studies the relationship between politics and business and the second studies how board attributes and director characteristics affect the firm in important decisions such as executive compensation. At a specific level, this paper examines the behavior of politically connected directors, as influenced by their political ideology, on decisions related to top executive compensation, pay dispersion within the firm and the performance-pay link.

After controlling for other characteristics of the sample firms, we find that firms with politically connected outside directors grant a lower level of top executive compensation. In the context of China, this may suggest that firms with politically connected boards would avoid payment of large executive compensation possibly for

\footnotetext{
${ }^{4}$ For the sake of parsimony these results are available upon request
} 
the purpose of social harmony. Politically connected directors may help adhere to the political goal of achieving a harmonious society set up by the Chinese government as the top priority (Zhang and Liu, 2009). This may explain why there is a negative association between politically connected directors and top executive pay. It is plausible therefore, that aligning the interests of management and those of shareholders is not the priority for politically connected boards. Our findings possibly suggest that politically connected directors, who are embedded in the Chinese institutional context, are more likely to act as an intermediary by reinforcing government expectations with regard to executive remunerations. Our findings also provide a more complete picture about the impact of the unique characteristic of board directors in China.

We have also found evidence which shows that there is a negative association between politically connected outside directors and pay dispersion. Our findings imply that a low pay dispersion is rooted both in the institutional context that places great emphasis on the equality of pay between managers and workers and the long held values of board directors who help to enhance such equality.

We go a step further to examine how the presence of politically connected directors affects the link between top executive pay and firm performance. We found that politically connected directors do not only affect top executive pay directly, but also indirectly impact the link between executive compensation and firm performance. These results support our overall line of argument that the corporate decisions made by politically connected directors in China are subject to social comparison processes and reflect communist values of equality. Given, therefore, the political ideology of politically connected directors, our findings are justifiably explained through the lens of social comparison and move beyond an agency 
theoretical perspective that rationalizes the positive association between executive pay and performance.

This paper claims a number of contributions to the field of corporate governance. Broadly, our paper contributes to the stream of research on the determinants of top executive compensation. It does this by improving our understanding of an important but understudied type of outside directors, namely former or current politicians/government officials, in determining top executive compensation and pay dispersion. Specifically, it contributes to the literature on political intervention in corporate governance in general and top executive compensation in particular.

Moreover, our study adds to the literature on corporate governance by suggesting that outside directors who share the norms and values of the state are more likely to promote the interests and ideology of the latter.

In addition, our paper contributes to better understanding and further application of social comparison theory in two important ways. First, we apply social comparison theory to understand pay dispersion across the firm beyond top management teams (TMTs), thus broadening previous studies in this area. Such an extension enriches our understanding of how the political ideology of board directors affects pay dispersion in the context with socialist traditions, indeed where 'the setting of executive compensation has several unique attributes that support a social explanation’ (Finkelstein and Hambrick, 1996: 275).

Second, in contrast to previous studies that have demonstrated the potential increase of remuneration following social comparison processes (Fredrickson et al., 2010), our study shows that the same processes could be used resulting in lower levels of top executive remuneration. 
Our findings have important theoretical implications for the role of outside directors in different institutional contexts with different levels of government intervention. Moreover, our findings carry some policy and managerial implications. The results from the study suggest that politically connected outside directors have played dual roles in helping firms gain key resources and reinforce government expectations with regard to top executive pay and pay dispersion. Hence, appointing former government officials as outside directors may help firms gain legitimacy and promote social harmony by designing acceptable executive compensation.

\section{Limitations and future research}

Like all research, this study is not exempt from limitations. First, our use of secondary data on issues of social comparison carries inherent limitations. Like all empirical studies on executive compensation that assume board involvement but rely on archival data (e.g., Oreilly et al., 1988), we did not assess the actual process by which the board sets executives' pay. Thus, even though previous research indicates that social-psychological processes that influence pay allocation at lower levels generalize well to board members (Fredrickson et al., 2010; Westphal and Zajac, 1995, 1997) we do not know how the issue of social comparisons is invoked in the process of determining top executive pay, particularly where politics and business are mutually important. Here, the way forward should be to employ more grounded approaches of data collection such as the use of interviews.

Second, while we have based our arguments on the uniqueness of the institutional environment, China's approach to business is fast changing. While arguments on path dependence may suggest that continuity is likely to win over radical change, the notion of equality within the Chinese society is facing great challenges from the forces of globalization, and is likely to fade with time. It would 
be interesting to see whether after a number of years Chinese firms continue to use politically connected directors or not, or whether such politically connected directors continue to hold and apply current political ideology on executive compensation and other corporate decisions.

Third, our measure of political connections is limited, and the nature of our data does not have a fine-grained distinction of who is on the board except for politically connected directors. Future research can develop a more fine grained analysis of the more detailed characteristics of the board of directors.

Finally, only aggregate salary and bonuses for the three highest paid executives are disclosed by Chinese listed firms, and using average top-three executive pay in our estimation may lack variation relative to individual pay. Moreover, our data on top executive compensation does not include long-term forms of pay such as stock options. However, as a practical matter, stock options have not been a common component of top executive pay in China. Relatedly, the use of the committee system, similar to other Asian countries (Chizema and Shinozawa, 2012), is still in its infancy in China. It is therefore difficult to find out who actually is involved with the duties of a compensation committee in many firms. With changes taking place in the governance of firms in China, accompanied by greater corporate disclosure and possible widespread use of board committees, future studies could examine the effect of outside directors on the various components of individual top executive compensation.

\section{Conclusions}

Using a unique dataset of Chinese listed firms, we provide new conceptual and empirical insights into the determinants of top executive pay. Drawing on social comparison theory, this is one of the first studies to examine the impact of political 
connections on top executive compensation and firm pay dispersion in the context of a large emerging economy. We have found that top executive pay and pay dispersion are negatively affected by politically connected outsider directors. Political connections weaken the relationship between performance and pay in an institutional context with socialist traditions.

\section{REFERENCES}

Adithipyangkul P, Alon L, Zhang T. 2011. Executive perks: Compensation and corporate performance in China. Asia Pacific Journal of Management 28: 401425.

Agrawal A, Knoeber CR. 2001. Do some outside directors play a political role? Journal of Law and Economics 44(1): 179-198.

Baker G, Jensen M, Murphy K. 1988. Compensation and incentives: Practice vs. theory. Journal of Finance 18: 593-616.

Baum CF, Schaffer ME, Stillman S. 2003. Instrumental variables and GMM: Estimation and testing. Stata Journal 3: 1-31.

Baysinger BD, Hoskisson RE. 1990. The composition of board of directors and strategic control: Effects on corporate strategy. Academy of Management Journal 15: 72-87.

Bebchuk L, Fried J, Walker DI. 2002. Managerial power and rent extraction in the design of executive compensation. The University of Chicago Law Review 69(3): 751-846.

Bebchuk L, Fried J. 2004. Pay without Performance: The Unfulfilled Promise of Executive Compensation. Harvard University Press: Cambridge, MA.

Benito A, Conyon MJ. 1999. The governance of directors' pay: Evidence from UK companies. Journal of Management and Governance 3: 117-136.

Bloom M. 1999. The performance effects of pay dispersion in individuals and organizations. Academy of Management Journal 42: 25-40.

Bloom M, Michel J. 2002. The relationship among organizational context, pay dispersion, and managerial turnover. Academy of Management Journal 45: 33-42. 
Blundell R, Bond S. 1998. Initial conditions and moment restrictions in dynamic panel data models. Journal of Econometrics 87: 115-143

Boycko M, Shleifer A, Vishny RW. 1996. A theory of privatization. The Economic Journal 106: 309-319.

Boyd B. 1994. Board control and CEO compensation. Strategic Management Journal 16: $301-312$.

Brambor T, Clark WR, Golder M. 2006. Understanding interaction models: Improving empirical analyses. Political Analysis 14: 63-82.

Brandt L, Li H. 2003. Bank discrimination in transition economies: Ideology, information or incentives? Journal of Comparative Economics 31: 387-413.

Buck T, Liu X, Skovoroda R. 2008. Top executive pay in China: a new laboratory for research? Journal of International Business Studies 39: 833-850.

Carpenter MA, Sanders WG. 2002. Top management team compensation: the missing link between CEO pay and firm performance. Strategic Management Journal 23(4): 367-375.

Carpenter MA, Geletkanycz M, Sanders WG. 2004. Upper echelons research revisited: Antecedents, elements, and consequences of top management team composition. Journal of Management 30: 749-778.

Chan HS, Ma J. 2011. How are they paid? A study of civil service pay in China. International Review of Administrative Sciences 77: 294-321.

Chan HS, Li S. 2007. Civil service law in the People’s Republic of China: A return to cadre personnel management. Public Administration Review 67: 383-398.

Che J. 2002. Rent seeking and government ownership of firms: An application to China's township-village enterprises. Journal of Comparative Economics 30: 781-811.

Chen J, Liu X, Li W. 2010. The effect of insider control and global benchmarks on Chinese executive compensation. Corporate Governance: An International Review 18: 107-123.

Chizema A, Shinozawa Y. 2012. The 'Company with Committees': Change or Continuity in Japanese Corporate Governance? Journal of Management Studies 49: 77-101.

Conyon MJ, Peck SI. Board control, remuneration committees, and top management compensation. The Academy of Management Journal 41(2):146-157 
Conyon MJ, He L. 2011. Executive compensation and corporate governance in China. Journal of Corporate Finance 17: 1158-1175.

Conyon MJ, Peck SI, Sadler GV. 2001. Corporate tournaments and executive compensation: Evidence from the UK. Strategic Management Journal 22: 805815.

Core JE, Holthousen RW, Larcker DF. 1999. Corporate governance, chief executive officer compensation and firm performance. Journal of Financial Economics 51: 371-406.

Crossland C, Hambrick D. 2011. Differences in managerial discretion across countries: How nation-level institutions affect the degree to which CEOs matter. Strategic Management Journal 32: 797-819.

Cull R, Xu LC. 2005. Institutions, ownership and finance: The determinants of profit reinvestment among Chinese firms. Journal of Financial Economics 77: 117-146.

Dalton DR, Daily CM, Ellstrand AE, Johnson JL. 1998. Meta-analytic reviews of board composition, leadership structure, and financial performance. Strategic Management Journal 19: 269-290.

Daily CM, Dalton DR, Cannella Jr AA. 2003. Corporate governance: Decades of dialogue and data. The Academy of Management Review 28(3): 371-382.

Daily CM, Dalton DR. 1997. Separate, but not independent: Board leadership structure in large corporations. Corporate Governance 5: 126-136.

Delios A, Wu ZJ, Zhou N. 2006. A new perspective on ownership identities in China's listed companies. Management and Organization Review 2: 319-343.

De Soto H. 1989. The Other Path: The Invisible Revolution in the Third Worlds, Harper and Row: New York.

Deutsch Y. 2005. The impact of board composition on firms' critical decisions: A meta-analytic review. Journal of Management 31: 424-444.

Dinç IS. 2004. Politicians and banks: Political influences on government -owned banks in emerging countries. Journal of Financial Economics 77: 453-479.

Du J, Girma S. 2010. Red capitalists: Political connections and firm performance in China. Kyklos 63: 530-545.

Ezzamel M, Watson R. 1998. Market comparison earnings and the bidding-up of executive cash compensation: Evidence from the UK. Academy of Management Journal 41: 221-231. 
Fama E, Jensen M. 1983. Agency problems and residual claims. Journal of Law and Economics 26: 327-349.

Faccio, M. 2006. Politically connected firms. American Economic Review 96: 369386.

Faccio M. 2010. Differences between politically connected and non-connected firms: A cross-country analysis. Financial Management Autumn: 905-927.

Faccio M, Masulis RW, McConnell JJ. 2006. Political connections and corporate bailouts. Journal of Finance 61: 2597-2635.

Festinger L. 1954. A theory of social comparison processes. Human Relations 7: 117140.

Fich EM, Shivdasani A. 2006. Are busy boards effective monitors? Journal of Finance 61: 689-724.

Filatotchev I, Allcock D. 2010. Corporate governance and executive remuneration: A contingency framework. Academy of Management Perspective February: 20-33.

Finkelstein S, Hambrick D. 1989. Chief executive compensation: a study of the intersection of markets and political processes. Strategic Management Journal 10: $121-134$.

Finkelstein S, Hambrick D. 1996. Strategic Leadership: Top Executives and their Effects on Organizations (West's Strategic Management Series). West: St. Paul, MN.

Firth PM, Fung Y, Rui OM. 2006. Corporate performance and CEO compensation in China. Journal of Corporate Finance 12(4): 693-714.

Firth PM, Fung Y, Rui OM. 2007. How ownership and corporate governance influence chief executive pay in China's listed firms. Journal of Business Research 60(7): 776-785.

Fredrickson JW, Davies-Blake A, Sanders WMG. 2010. Sharing the wealth: Social comparisons and pay dispersion in the CEO's top team. Strategic Management Journal 31: 1031-1053.

Gibbons R, Murphy K. 1992. Optimal incentive contracts in the presence of career concerns: Theory and evidence. Journal of Political Economy 100: 468-505.

Goldman E, Rocholl J, So J. 2009. Do politically connected boards affect firm value. Review of Financial Studies 22: 2331-2360. 
Gomez-Mejia LR. 1994. Executive compensation. In G. Ferris (Ed.), Research in personnel and human resources management, 12: 175-213. Greenwich, CT: JAI Press.

Guner AB, Malmendier U, Tate G. 2008. Financial expertise of directors. Journal of Financial Economics 88: 323-354.

Graffin SD, Wade JB, Porac J, McNamee RC. 2008. The impact of CEO status diffusion on the economic outcomes of other senior managers. Organization Science 19: 457-474.

Hall BJ, Liebman JB. 1998. Are CEOs really paid like bureaucrats? Quarterly Journal of Economics 111: 653-691.

Hallock KF. 1997. Reciprocally interlocking boards of directors and executive compensation. Journal of Financial and Quantitative Analysis 32: 331-344.

Hillman AJ. 2005. Politicians on the board of directors: Do connections affect the bottom line? Journal of Management 31: 464-481.

Hillman AJ, Cannella AA, Harris IC. 2002. Women and minorities in the boardroom: How do directors differ? Journal of Management 28: 747-763.

Hillman AJ, Dalziel T. 2003. Boards of directors and firm performance: Integrating agency and resource dependence perspectives. Academy of Management Review 28: 383-396.

Hofstede G. 2003. Culture's Consequences: Comparing Values, Behaviours, Institutions, and Organizations across Nations. Sage: Newbury Park, CA.

Hogan T, McPheters L. 1980. Executive compensation: Performance vs. personal characteristics. Southern Economic Journal 46: 1060-1068.

Jensen M, Murphy K. 2010. CEO incentives. It's not how much you pay, but how. Journal of Applied Corporate Finance, 22(1): 64-76.

Johnson JL, Daily CM, Ellstrand AE. 1996. Boards of directors: A review and research agenda. Journal of Management 22(3): 409-438.

Johnson S, Mitton T. 2003. Cronyism and capital controls: Evidence from Malaysia. Journal of Financial Economics 67: 351-382.

Jost JT. 2006. The end of the end of ideology. American Psychologist 61: 651-670.

Kato TK, Long CX. 2006. Executive compensation, firm performance, and corporate governance in China: Evidence from listed firms in the Shanghai and Shenzhen Stock Exchanges. Economic Development and Cultural Change 54(4): 945-983. 
Kato T, Kim W, Lee JH. 2005. Executive compensation, firm performance, and chaebols in Korea. IZA Discussion Paper \#1783, Institute for the Study of Labor (IZA): Bonn.

Keister LA. 2004. Capital structure in transition: The transformation of financial strategies in China’s emerging economy. Organization Science 15: 145-159.

Kulik C, Ambrose M. 1992. Personal and situational determinants of referent choice. Academy of Management Review 17: 212-237.

Kumar P, Sivaramakrishnan K. 2008. Who monitors the monitor? The effect of board independence on executive compensation and firm value. Review of Financial Studies 21(3): 1371-1401

Lambert R, Larcker D, Weigelt K. 1993. The structure of organizational incentives. Administrative Science Quarterly 38: 438-461.

Layman GC. 1997. Religion and political behavior in the United States: The impact of beliefs, affiliations, and commitment from 1980 to 1994. Public Opinion Quarterly 61: 288-316.

Lazear EP. 1989. Pay equality and industrial politics. Journal of Political Economy 97: 561- 580.

Lazear EP, Rosen S. 1981. Rank-order tournaments as optimum labor contracts. Journal of Political Economy 89: 841-864.

Leventhal GS, Michaels JW, Sanford C. 1972. Inequity and interpersonal conflict: Reward allocation and secrecy about reward as methods of preventing conflict. Journal of Personality and Social Psychology 23: 88-102.

Main B, O’Reilly C, Wade J. 1993. Top executive pay: Tournament or teamwork? Journal of Labor Economics 11: 606-628.

Markoczy L, Sun SL, Peng MW, Shi W, Ren B. 2013. Social network contingency, symbolic management and boundary stretching. Strategic Management Journal 34: 1367-1387.

Mengistae T, Xu LXC. 2004. Agency theory and executive compensation: The case of Chinese state-owned enterprises. Journal of Labor Economics 22(3): 615-637

Milkovich GT, Gerhart B, Hannon J. 1991. The effects of research and development intensity on managerial compensation in large organizations. Journal of High Technology Management Research 2: 133-150.

Milkovich GT, Newman JM. 1999. Compensation. Irwin: Homewood, IL. 
Murphy K. 1999. Executive compensation. In Handbook of Labor Economics (Handbooks in Economics)(Volume 3a), Ashenfelter O, Card D (eds). Elsevier: Amsterdam, 2485-2563.

Ofek E, Yermack D. 2000. Taking stock: Equity-based compensation and the evolution of managerial ownership. Journal of Finance LV: 1367-1384.

O’Reilly CA, Main BGM, Crystal GS. 1988. CEO compensation as tournament and social comparison: a tale of two theories. Administrative Science Quarterly 33: 257-274.

Papke LE, Wooldridge JM. 1996. Econometric methods for fractional response variables with an application to $401(\mathrm{~K})$ plan participation rates. Journal of Applied Econometrics 11(6): 619-32.

Pfeffer J, Salancik GR. 1978. The External Control of Organizations: A Resource Dependence Perspective. Harper and Row: New York.

Pfeffer J, Langton N. 1993. The effect of wage dispersion on satisfaction, productivity, and working collaboratively: Evidence from college and university faculty. Administrative Science Quarterly 38: 382-407.

Rost K, Osterloh M. 2009. Management fashion pay-for-performance for CEOs. Schmalenbach Business Review, 61(2): 119-149.

Shi J, Wu Z. 1993. Chinese Civil Servants’ Wages. Beijing: Reform Press.

Siegel PA, Hambrick DC. 2005. Pay disparities within top management groups: evidence of harmful effects on performance of high-technology firms. Organization Science 16: 259-274.

Stern I, Westphal JD. 2010. Stealthy footsteps to the boardroom: Executives' backgrounds, sophisticated interpersonal influence behavior, and board appointments. Administrative Science Quarterly 55: 278-319.

Tosi HL, Katz JP, Gomez-Mejia LR. 1997. Disaggregating the agency contract: The effects of monitoring, incentive alignment, and term in office on agency decision making. Academy of Management Journal 40: 584-602.

Tosi HL, Werner S, Katz JP, Gomez-Mejia LR. 2000. How much does performance matter? A meta-analysis of CEO pay studies. Journal of Management 26: 301339.

Wade JB, O’Reilly CA, Pollock TG. 2006. Overpaid CEOs and underpaid managers: Fairness and executive compensation. Organization Science 17: 527-544. 
Walster E, Berscheid E, Walster G. 1973. New directions in equity re-search. Journal of Personality and Social Psychology 25: 151-176.

Westphal JD, Zajac EJ. 1995. Who shall govern? CEO/board power, demographic similarity, and new director similarity. Administrative Science Quarterly 40: 6083.

Westphal JD, Zajac EJ. 1997. Defections from the inner circle: social exchange, reciprocity and the diffusion of board independence in US corporations. Administrative Science Quarterly 42: 161-183.

Williamson O. 1988. Corporate finance and corporate governance. Journal of Financial Economics 43: 567-591.

Wooldridge JM. 2002. Econometric Analysis of Cross Section and Panel Data. MIT Press: New York.

Wright P, Kroll M, Elenkov D. 2002. Acquisition returns, increase in firm size, and chief executive officer compensation: the moderating role of monitoring. Academy of Management Journal 45:599-608.

Zenger T. 1992. Why do employers only reward extreme performance? Examining the relationships among performance, pay and turnover. Administrative Science Quarterly 37: 198-219.

Zhang W, Liu X. 2009. Success and challenges: an overview of China's economic growth and reform since 1978. Journal of Chinese Economic and Business Studies 7(2): 127-138. 
Table 1: Estimates of median executive pay sensitivities ${ }^{5}$ and elasticities ${ }^{6}$ compared (salary and bonus only)

\begin{tabular}{|c|c|c|c|c|}
\hline $\begin{array}{l}\text { Researcher(s) } \\
\text { (date) }\end{array}$ & $\begin{array}{c}\text { Country } \\
\text { (Years studied) }\end{array}$ & $\begin{array}{l}\text { Performanceź } \\
\text { Pay Sensitivity }\end{array}$ & $\begin{array}{l}\text { Performanceź } \\
\text { Pay Elasticity }\end{array}$ & $\begin{array}{l}\text { Payź Performance } \\
\text { Elasticity }\end{array}$ \\
\hline $\begin{array}{c}\text { Hall and } \\
\text { Liebman (1998) }\end{array}$ & $\begin{array}{c}\text { USA } \\
(1980-1994)\end{array}$ & - & 0.22 & - \\
\hline $\begin{array}{c}\text { Benito \& } \\
\text { Conyon (1999) }\end{array}$ & $\begin{array}{c}\text { UK } \\
(1990-1996)\end{array}$ & - & 0.26 & - \\
\hline $\begin{array}{l}\text { Kato, Kim and } \\
\text { Lee (2005) }\end{array}$ & S. Korea & - & 0.194 & - \\
\hline $\begin{array}{l}\text { Firth, Fung, and } \\
\text { Rui (2006) }\end{array}$ & $\begin{array}{c}\text { China } \\
(1998-2000)\end{array}$ & 0.021 (insig.) & - & - \\
\hline $\begin{array}{l}\text { Kato and Long } \\
\text { (2006) }\end{array}$ & $\begin{array}{c}\text { China } \\
(1998-2002)\end{array}$ & 0.053 & 0.369 & - \\
\hline $\begin{array}{l}\text { Buck, Liu and } \\
\text { Skovoroda } \\
\text { (2008) }\end{array}$ & $\begin{array}{c}\text { China } \\
(2000-2003)\end{array}$ & $\begin{array}{c}0.027^{* *} \\
(3.44)\end{array}$ & $\begin{array}{l}0.250^{*} \\
(2.71)\end{array}$ & $\begin{array}{c}0.015^{*} \\
(2.49)\end{array}$ \\
\hline $\begin{array}{c}\text { Current study } \\
\text { (2013) }\end{array}$ & $\begin{array}{c}\text { China } \\
(2002-2008)\end{array}$ & & $\begin{array}{l}0.271 * * * \\
(3.61)\end{array}$ & $\begin{array}{l}0.036 * \\
(2.27)\end{array}$ \\
\hline
\end{tabular}

*, **, and *** represent significance at the $0.05,0.01$ and 0.001 levels, respectively.

${ }^{5}$ Performance-pay sensitivity shows the absolute increment to pay associated with a 1000 unit (e.g., \$) increase in shareholder value: so a sensitivity of 0.053 (for China; Kato and Long, 2006) indicates that an additional $\$ 1000$ of shareholder value is associated with 5.3 cents of additional executive pay. It is calculated by regressing changes in executive pay on changes in shareholder value.

${ }^{6}$ Performance-pay elasticity shows the percentage responsiveness of pay to a percentage change in performance. For example, an elasticity of 0.10 denotes that a CEO associated with a $20 \%$ rate of return would be paid $1 \%$ more than a CEO associated with $10 \%$ (Hall and Liebman, 1998: 654). It is calculated by regressing the change in the log of executive pay on change in the log of shareholder value. 
Table 2: Descriptive statistics and correlation matrix

\begin{tabular}{|c|c|c|c|c|c|c|c|c|c|c|c|c|c|c|c|c|c|c|c|}
\hline & Mean & $\begin{array}{l}\text { Std. } \\
\text { Dev. }\end{array}$ & Min & Max & 1 & 2 & 3 & 4 & 5 & 6 & 7 & 8 & 9 & 10 & 11 & 12 & 13 & 14 & 15 \\
\hline $1 \mathrm{TE}$ cash pay & 12.04 & 0.84 & 9.16 & 15.36 & & & & & & & & & & & & & & & \\
\hline $\begin{array}{l}2 \text { Pay } \\
\text { dispersion }\end{array}$ & -1.62 & 1.41 & -6.33 & 5.32 & -0.386 & & & & & & & & & & & & & & \\
\hline 3Performance & 0.03 & 0.44 & -7.09 & 12.76 & 0.124 & -0.028 & & & & & & & & & & & & & \\
\hline $\begin{array}{l}4 \text { Political } \\
\text { connection }\end{array}$ & 0.04 & 0.08 & 0.00 & 0.43 & 0.026 & 0.023 & 0.001 & & & & & & & & & & & & \\
\hline 5 Board size & 9.07 & 1.97 & 4.00 & 20.00 & 0.183 & -0.055 & 0.049 & -0.004 & & & & & & & & & & & \\
\hline $\begin{array}{l}6 \text { Average age } \\
\text { of TE }\end{array}$ & 46.61 & 3.25 & 36.00 & 59.00 & 0.187 & -0.019 & 0.053 & 0.136 & 0.171 & & & & & & & & & & \\
\hline 7 CEO change & 0.31 & 0.46 & 0.00 & 1.00 & -0.106 & 0.048 & -0.076 & 0.005 & 0.009 & -0.113 & & & & & & & & & \\
\hline $\begin{array}{l}8 \text { State share } \\
\text { holding }\end{array}$ & 0.32 & 0.24 & 0.00 & 0.97 & -0.087 & 0.091 & 0.029 & 0.038 & 0.185 & 0.218 & 0.009 & & & & & & & & \\
\hline $\begin{array}{l}9 \text { Foreign share } \\
\text { holding }\end{array}$ & 0.01 & 0.05 & 0.00 & 0.64 & 0.097 & -0.082 & -0.014 & 0.003 & 0.005 & 0.042 & 0.029 & -0.106 & & & & & & & \\
\hline 10 Cross listing & 0.06 & 0.24 & 0.00 & 1.00 & 0.137 & -0.083 & -0.008 & -0.004 & 0.049 & 0.039 & 0.007 & -0.093 & 0.783 & & & & & & \\
\hline $\begin{array}{l}11 \text { TE equity } \\
\text { ownership }\end{array}$ & 0.003 & 0.03 & 0.00 & 0.75 & 0.053 & -0.013 & 0.011 & -0.016 & -0.055 & -0.043 & -0.042 & -0.119 & -0.013 & -0.001 & & & & & \\
\hline $\begin{array}{l}12 \text { Debt-equity } \\
\text { ratio }\end{array}$ & 0.56 & 0.76 & 0.01 & 43.08 & -0.027 & -0.010 & -0.064 & 0.028 & -0.032 & -0.016 & 0.041 & -0.047 & 0.004 & 0.007 & -0.024 & & & & \\
\hline 13 Firm size & 9.27 & 0.45 & 6.76 & 11.88 & 0.395 & -0.113 & 0.139 & 0.062 & 0.272 & 0.304 & -0.089 & 0.148 & 0.042 & 0.057 & -0.050 & -0.120 & & & \\
\hline 14 Firm age & 10.75 & 4.41 & 2.00 & 50.00 & 0.191 & -0.090 & -0.018 & 0.011 & -0.066 & 0.046 & 0.041 & -0.333 & 0.023 & -0.002 & -0.062 & 0.088 & -0.026 & & \\
\hline 15 Average Pay & 10.09 & 1.04 & 7.32 & 13.67 & 0.408 & 0.654 & 0.073 & 0.040 & 0.094 & 0.126 & -0.032 & 0.023 & -0.006 & 0.026 & 0.031 & -0.034 & 0.201 & 0.046 & \\
\hline
\end{tabular}

Notes: 1 . All correlation coefficients more than 0.033 or less than -0.033 are significant at the $5 \%$ level or higher.

2. TE denotes top executive. 
Table 3: Determinants of politically connected outside directors DV: Political connections (binary logit model)

\begin{tabular}{crr}
\hline & Coefficients & Std. Error \\
\hline Cross listing & -0.573 & 0.545 \\
State share holding & 0.246 & 0.344 \\
Foreign share & 1.577 & 2.303 \\
holding & & \\
Debt-equity ratio & 6.522 & 4.713 \\
Firm size & 1.728 & 1.157 \\
Firm age & -0.072 & 0.054 \\
Year dummy & 0.394 & 0.455 \\
Industry dummies & Included & Included \\
\hline Observations & 5111 & \\
\hline
\end{tabular}


Table 4: Results from testing top executive pay

\begin{tabular}{|c|c|c|}
\hline DV: TE cash pay & Model 1 & Model 2 \\
\hline & GMM & GMM \\
\hline Political connections (PC) & $\begin{array}{c}-0.361^{* *} \\
(0.129)\end{array}$ & $\begin{array}{c}-0.257 \dagger \\
(0.135)\end{array}$ \\
\hline Performance(-1) & $\begin{array}{c}0.528 * * * \\
(0.050)\end{array}$ & $\begin{array}{c}0.453^{* *} \\
(0.169)\end{array}$ \\
\hline PC X Performance(-1) & & $\begin{array}{l}-2.938^{*} \\
(1.442)\end{array}$ \\
\hline Cross listing & $\begin{array}{c}0.358^{* * *} \\
(0.063)\end{array}$ & $\begin{array}{c}0.352 * * * \\
(0.062)\end{array}$ \\
\hline State share holding & $\begin{array}{c}-0.188 * * * \\
(0.047)\end{array}$ & $\begin{array}{c}-0.203^{* * * *} \\
(0.046)\end{array}$ \\
\hline Foreign shareholding & $\begin{array}{l}-0.075 \\
(0.293)\end{array}$ & $\begin{array}{l}-0.113 \\
(0.289)\end{array}$ \\
\hline Board size & $\begin{array}{c}0.043^{* * *} \\
(0.005)\end{array}$ & $\begin{array}{c}0.044^{* * *} \\
(0.005)\end{array}$ \\
\hline Average age of TE & $\begin{array}{l}0.009 * * \\
(0.003)\end{array}$ & $\begin{array}{l}0.010 * * \\
(0.003)\end{array}$ \\
\hline CEO change & $\begin{array}{c}-0.119 * * * \\
(0.021)\end{array}$ & $\begin{array}{c}-0.121^{* * *} \\
(0.021)\end{array}$ \\
\hline Debt-equity ratio & $\begin{array}{l}0.027^{*} \\
(0.012)\end{array}$ & $\begin{array}{c}0.019 \\
(0.013)\end{array}$ \\
\hline Firm size & $\begin{array}{c}0.526 * * * \\
(0.025)\end{array}$ & $\begin{array}{c}0.550 * * * \\
(0.027)\end{array}$ \\
\hline Firm age & $\begin{array}{c}0.016^{* * *} \\
(0.003)\end{array}$ & $\begin{array}{c}0.016^{* * *} \\
(0.003)\end{array}$ \\
\hline TE equity ownership & $\begin{array}{c}1.570^{* * *} \\
(0.311)\end{array}$ & $\begin{array}{c}1.587^{* * *} \\
(0.308)\end{array}$ \\
\hline Industry dummies & Included & Included \\
\hline Year Dummies & Included & Included \\
\hline $\mathrm{R}^{\wedge} 2$ & 0.242 & 0.266 \\
\hline Observations & 5111 & 5111 \\
\hline Sargan statistic & $\begin{array}{c}1.095 \\
\text { p-value }=0.579\end{array}$ & $\begin{array}{c}5.192 \\
\text { p-value }=0.158\end{array}$ \\
\hline
\end{tabular}

Note: $\dagger, *, * *$, and $* * *$ represent significance at the $0.1,0.05,0.01$ and 0.001 levels, respectively. Standard errors in parentheses 
Table 5: Results from testing pay dispersion

\begin{tabular}{|c|c|c|}
\hline & DV: Pay dispersion & DV: Average pay \\
\hline & OLS & OLS \\
\hline \multirow[t]{2}{*}{ Political connections } & $0.528^{*}$ & 0.004 \\
\hline & $(0.240)$ & $(0.176)$ \\
\hline \multirow{2}{*}{ Performance(-1) } & $-0.094 \dagger$ & $0.099 * *$ \\
\hline & $(0.050)$ & $(0.036)$ \\
\hline \multirow[t]{2}{*}{ Cross listing } & $-0.218 \dagger$ & $0.177^{*}$ \\
\hline & $(0.118)$ & $(0.086)$ \\
\hline \multirow[t]{2}{*}{ State shareholding } & $0.393 * * *$ & $0.106 \dagger$ \\
\hline & $(0.087)$ & $(0.064)$ \\
\hline \multirow[t]{2}{*}{ Foreign shareholding } & $-1.085^{*}$ & $-0.920 * *$ \\
\hline & $(0.545)$ & $(0.400)$ \\
\hline \multirow[t]{2}{*}{ Board size } & $-0.028 * *$ & $0.023 * * *$ \\
\hline & $(0.010)$ & $(0.007)$ \\
\hline \multirow{2}{*}{ Average age of TE } & 0.004 & $0.013 * *$ \\
\hline & $(0.006)$ & $(0.005)$ \\
\hline \multirow[t]{2}{*}{ CEO change } & $0.182 * * *$ & 0.013 \\
\hline & $(0.040)$ & $(0.029)$ \\
\hline \multirow[t]{2}{*}{ Debt-equity ratio } & $-0.038 \dagger$ & -0.020 \\
\hline & $(0.023)$ & $(0.017)$ \\
\hline \multirow[t]{2}{*}{ Firm size } & $-0.341 * * *$ & $0.297 * * *$ \\
\hline & $(0.046)$ & $(0.034)$ \\
\hline \multirow[t]{2}{*}{ Firm age } & $-0.025 * * *$ & $-0.008 *$ \\
\hline & $(0.005)$ & $(0.004)$ \\
\hline \multirow[t]{2}{*}{ TE equity ownership } & -0.205 & $1.469 * * *$ \\
\hline & $(0.579)$ & $(0.425)$ \\
\hline Industry dummies & Included & Included \\
\hline Year dummies & Included & Included \\
\hline $\bar{R} \wedge 2$ & 0.048 & 0.091 \\
\hline Observations & 5111 & 5111 \\
\hline
\end{tabular}

Note: $\dagger,{ }^{*}, * *$, and ${ }^{* * *}$ represent significance at the $0.1,0.05,0.01$ and 0.001 levels, respectively. Standard errors in parentheses 
Figure 1: The moderating effect of political connections on the link between top executive pay and firm performance

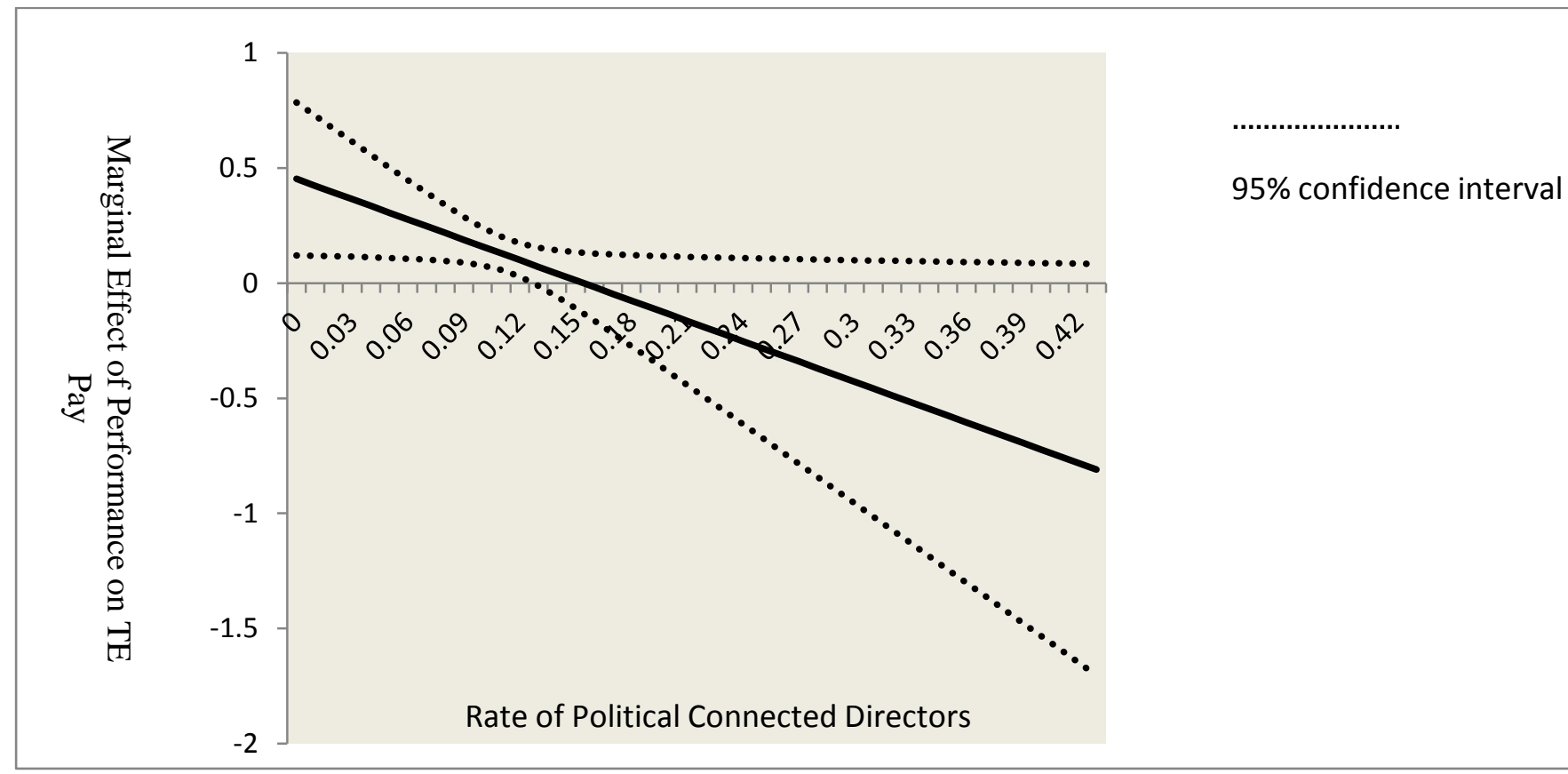

Figure 2: The combined effect of political connections and firm performance on top executive pay

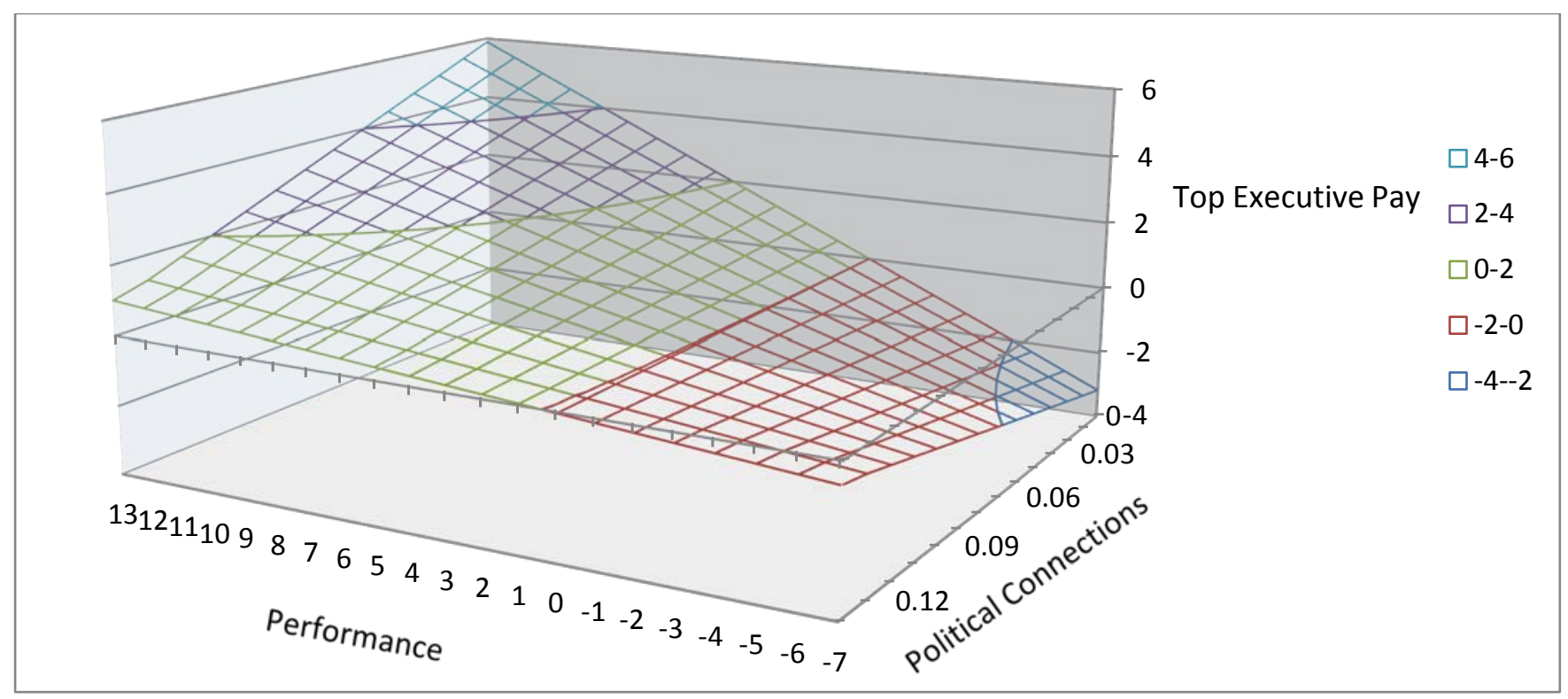

